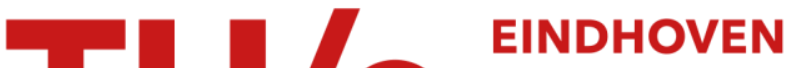

\section{Study of $\mathrm{Fe} / \mathrm{C}$ and $\mathrm{FeMo} / \mathrm{C}$ hydrodesulfurization catalysts : preparational aspects and metal support interaction}

\section{Citation for published version (APA):}

Ramselaar, W. L. T. M., Kraan, van der, A. M., \& Beer, de, V. H. J. (1986). Study of Fe/C and FeMo/C hydrodesulfurization catalysts : preparational aspects and metal support interaction. Hyperfine Interactions, 28(1-4), 895-898. https://doi.org/10.1007/BF02061588

DOI:

10.1007/BF02061588

Document status and date:

Published: 01/01/1986

\section{Document Version:}

Publisher's PDF, also known as Version of Record (includes final page, issue and volume numbers)

\section{Please check the document version of this publication:}

- A submitted manuscript is the version of the article upon submission and before peer-review. There can be important differences between the submitted version and the official published version of record. People interested in the research are advised to contact the author for the final version of the publication, or visit the $\mathrm{DOI}$ to the publisher's website.

- The final author version and the galley proof are versions of the publication after peer review.

- The final published version features the final layout of the paper including the volume, issue and page numbers.

Link to publication

\section{General rights}

Copyright and moral rights for the publications made accessible in the public portal are retained by the authors and/or other copyright owners and it is a condition of accessing publications that users recognise and abide by the legal requirements associated with these rights.

- Users may download and print one copy of any publication from the public portal for the purpose of private study or research.

- You may not further distribute the material or use it for any profit-making activity or commercial gain

- You may freely distribute the URL identifying the publication in the public portal.

If the publication is distributed under the terms of Article 25fa of the Dutch Copyright Act, indicated by the "Taverne" license above, please follow below link for the End User Agreement:

www.tue.nl/taverne

Take down policy

If you believe that this document breaches copyright please contact us at:

openaccess@tue.nl

providing details and we will investigate your claim. 


\title{
STUDY OF Fe/C AND FeMo/C HYDRODESULFURIZATION CATALYSTS: PREPARATIONAL ASPECTS AND METAL SUPPORT INTERACTION
}

\author{
W.L.T.M. RAMSELAAR and A.M. VAN DER KRAAN \\ Interuniversitair Reactor Instituut, $2629 \mathrm{JB}$ Delft, the Netherlands \\ V.H.J. DE BEER \\ Laboratory of Inorganic Chemistry and Catalysis, Eindhoven; \\ University of Technology, $5600 \mathrm{MB}$ Eindhoven, the Netherlands \\ From the Mössbauer spectra of various oxidic catalysts \\ precursors obtained at $4.2 \mathrm{~K}, 77 \mathrm{~K}$ and $300 \mathrm{~K}$, the sequences \\ in particle size and thermal motions relative to the \\ support are established.
}

\section{INTRODUCTION}

Hydrotreating catalysts are used for the upgrading of fossil fuel fractions. Several processes take place simultaneously, such as hydrocracking, removal of sulfur, nitrogen, oxygen and metals, and hydrogenation of olefins and aromatic hydrocarbons. At present, industrially employed hydrotreating catalysts consist of Mo and $i$ promoted with Co or Ni dispersed on a high-surface area alumina support. The catalysts are active in the sulfided state. Mössbauer emission spectroscopy has been very succesful in the chaxacterization of industrial hydrotreating catalysts $/ 1,2 /$.

Recently, carbon supported metal sulfides have attracted attention as favourable hydrotreating catalysts /3/. In particular, iron sulfide on carbon would be a potentially attractive catalyst, as iron is inexpensive and abundantly present. For Fe/C catalysts preparational aspects such as the kind of carbon-support and iron salt solution for impregnation, in relation to their catalytic properties, are described by Groot /4/. In his study Mössbauer spectroscopy has played an important role in characterizing the oxidic catalyst precursors. In addition, now we present the influence of the drying procedure and the solvent on the dispersion and related particlesupport interaction studied by Mössbauer spectroscopy.

\section{EXPERIMENT AND RESULTS}

The carbon-supported catalyst precursors are prepared by pore volume impregnation of Norit RX3-extra active carbon (aurface area $1190 \mathrm{~m} 2 / \mathrm{gr}$ ). An aqueous solution containing the desired amount of iron or molybdenum is added to the carbon support until the incipient wetness point is reached. As starting materials are used $\mathrm{Fe}\left(\mathrm{NO}_{3}\right)_{3} \cdot 9 \mathrm{H}_{2} \mathrm{O}$ (Merck, P.A.) and $\left(\mathrm{NH}_{4}\right)_{6} \mathrm{MO}_{7} \mathrm{O}_{24} \cdot 4 \mathrm{H}_{2} \mathrm{O}$ (Merck, > 998). The impregnated samples are dried at room temperature in different ways, in order to study the influence of the drying procedure. Optimum $\mathrm{Fe}-\mathrm{Mo} / \mathrm{C}$ catalysts are obtained by a sequential pore volume impregnation in which Mo is introduced prior to iron. All catalysts contain 2.7 wto $\mathrm{Fe}$, the $\mathrm{Fe}-\mathrm{Mo} / \mathrm{C}$ catalysts in addition 15 wt: Mo.

In order to obtain a highly active catalyst, a high dispersion of the supported iron particles is desirable. Mössbauer spectroscopy can in principle yield indirectly the important information on particle size in two ways: by studying the superparamagnetic transition temperature of the particles /5/ and by analyzing the recoiliess fraction as a function of temperature. 

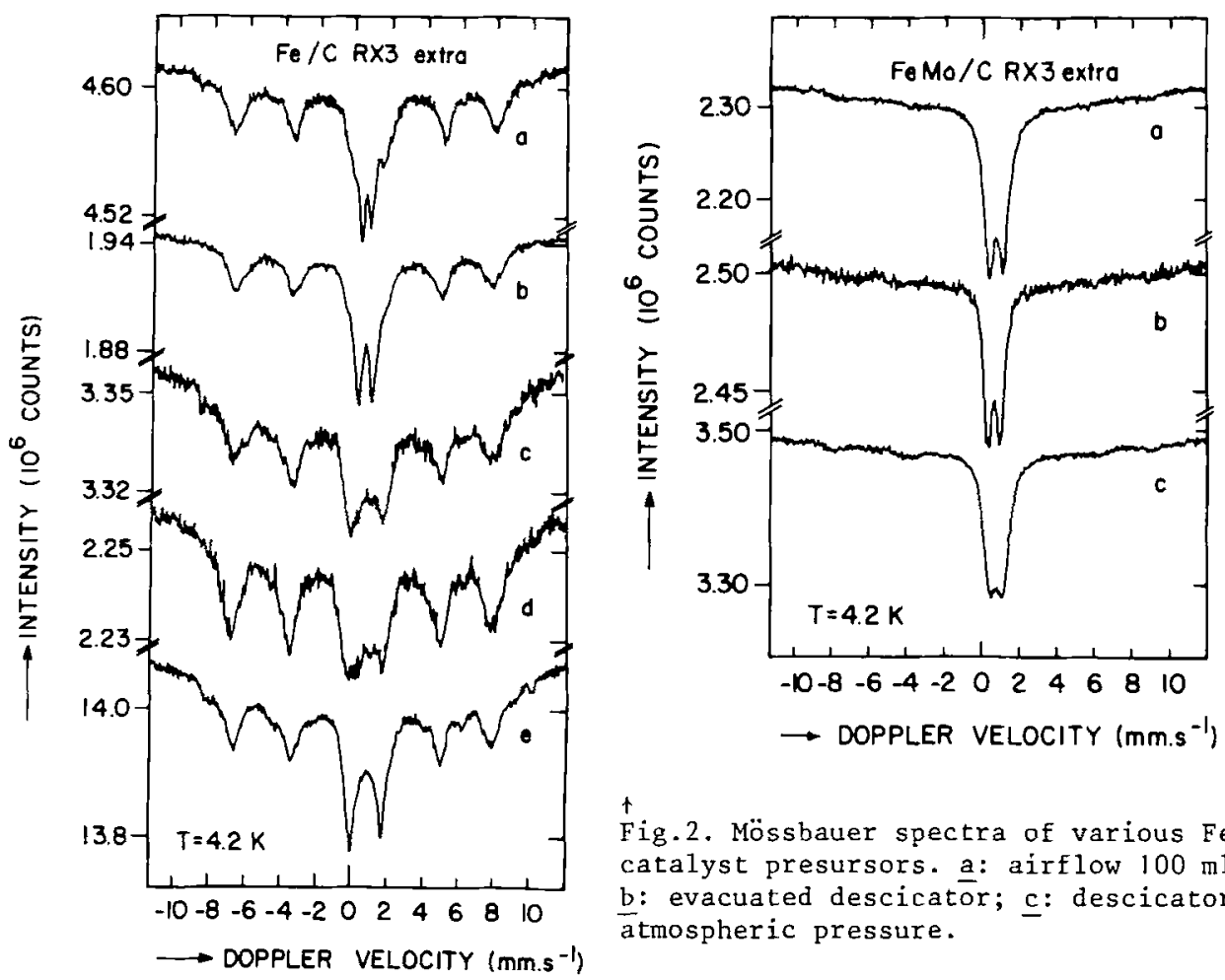

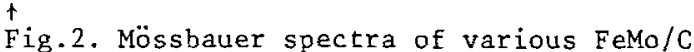
catalyst presursors. a: airflow $100 \mathrm{ml} / \mathrm{min}$; b: evacuated descicator; c: descicator at atmospheric pressure.

Fig. 1. Mössbauer spectra of various $\mathrm{Fe} / \mathrm{C}$ catalyst precursors. a: airflow $50 \mathrm{~m} 1 / \mathrm{min}$ $\left(\theta_{\mathrm{D}}=175 \mathrm{~K}\right)$; $\underline{b}$ : airflow $100 \mathrm{ml} / \mathrm{min}\left(\theta_{\mathrm{D}}=225 \mathrm{~K}\right) ; \mathrm{c}:$ airflow $500 \mathrm{ml} / \overline{\mathrm{min}}\left(\theta_{\mathrm{D}}=150 \mathrm{~K}\right)$;

$\mathrm{d}$ : descicator $\left(\theta_{\mathrm{D}}=150 \mathrm{~K}\right)$; e: solvent ethanol, airflow $100 \mathrm{ml} / \mathrm{min}\left(\theta_{\mathrm{D}}=125 \mathrm{~K}\right)$.

From the latter an effective Debye temperature $\left(\theta_{D}\right)$ can be determined /6/. However, Debye temperatures derived from the temperature dependence of the resonant absorption areas will be too low, when the supported catalyst particles in their totality perform thermal motions relative to the support /7/. Therefore we determine the sequence in the mean particle size of the Fe(III)oxide particles from the spectral contribution of the magnetic hyperfine sextuplet at a certain temperature. The thermal motions of the particles depend on the interaction strength between the particles and support. The lower the interaction strength, the larger the mobility of the particles over the support, leading more easily to sintering. So, by determining the effective Debye temperature $\theta_{D}$ from the temperature dependence of the resonant absorption area of the spectra, information is obtained about the interaction strength between the particles and support.

In Fig.l Mössbauer spectra recorded at $4.2 \mathrm{~K}$ are presented of the oxidic Fe/C catalyst precursor after differentdrying treatments. The effective Debye temperatures for these samples determined from the total resonant absorption areas of the spectra at $4.2 \mathrm{~K}$, $77 \mathrm{~K}$ and $300 \mathrm{~K}$ respectively are given in the captions of Fig.l. The impregnated sample is dried in a descicator above $\mathrm{P}_{2} \mathrm{O}_{5}$ for 7 days, or in an continuous airflow of $50 \mathrm{ml} / \mathrm{min}, 100 \mathrm{ml} / \mathrm{min}$ or $500 \mathrm{ml} / \mathrm{min}$ during $18 \mathrm{~h}$. Due to the phenomenon of superparamagnetism, an increase in spectral contribution of the magnetic hyperfine sextuplet means an increase 


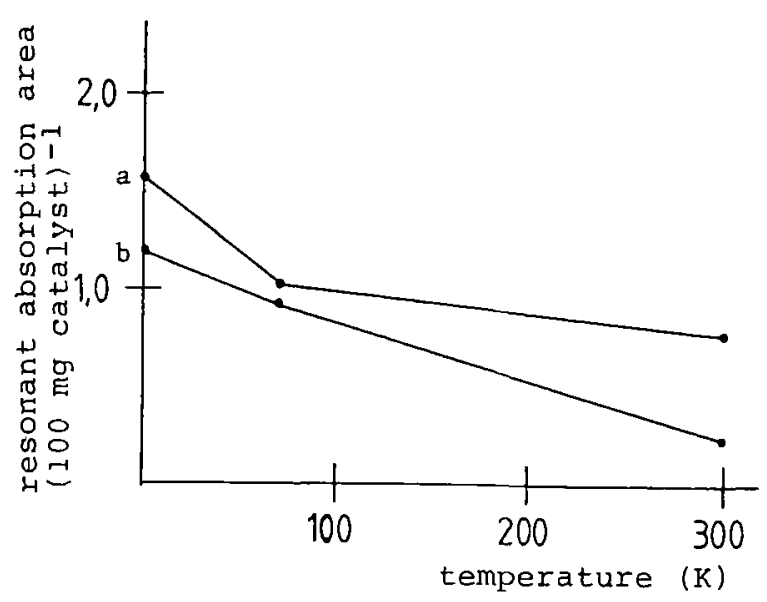

Fig.3. Temperature dependence of the resonant absorption area of $\mathrm{Fe} / \mathrm{C}$ catalyst precursor (dried in $50 \mathrm{ml} / \mathrm{min}$ airflow); a: paraffin embedded; b-: non embedded.

in mean particle size. Although only a little difference in mean particle size is observed for the samples dried in an airflow of 50 $\mathrm{ml} / \mathrm{min}$ and $100 \mathrm{ml} / \mathrm{min}$, it follows from Fig.l that by increasing as well as decreasing the evaporation rate of water, an increase in mean particle size is found.

The highest effective Debye temperature is found for the sample with the smallest mean particle size. So this sample will be the least sensitive to sintering.

Mössbauer spectra have been taken at room temperature of the sample dried in the descicator, after different periods of drying. The relative total resonant absorption area is directly after impregnation 0.27 , after one day in the descicator 0.51 , after two days 0.98 and after seven days 1.0. After two days in the descicator it is hardly possible to remove more water of the catalyst precursor. The thermal motions of the particles relative to the support are still large as follows from the effective Debye temperature (in the caption of Fig.1).

In Fig. 2 the Mössbauer spectra of the oxidic FeMo/C catalyst precursor after drying in airflow $(100 \mathrm{ml} / \mathrm{min})$ for $18 \mathrm{~h}$, or in a descicator above $\mathrm{P}_{2} \mathrm{O}_{5}$ or an evacuated $\left(3.10^{3} \mathrm{~Pa}\right)$ descicator above $\mathrm{P}_{2} \mathrm{O}_{5}$ are shown. Hardly any spectral contribution of a magnetic hyperfine sextuplet is found for the different samples, so the mean particle size of the iron(III) oxide particles will be the same and appears to be smaller in the $\mathrm{FeMo/C}$ than in the $\mathrm{Fe} / \mathrm{C}$ catalyst precursors. A comparison with data obtained by Jung et al /8/ and Niemantsverdriet et al /9/ for carbon-supported iron Fischer-Tropsch catalysts shows that the mean particle size of the iron(III) oxide particles in the FeMo/C samples is below $20 \mathrm{~A}$. For the three FeMo/C samples a same temperature dependence of the total resonant absorption area is found, which leads to a $\theta_{\mathrm{D}}$ of $150 \mathrm{~K}$.

To overcome the thermal motion of the particles relative to the support and the enhanced vibrations of the surface atoms, we have embedded a $\mathrm{Fe} / \mathrm{C}$ catalyst precursor in a paraffin matrix following Hayashi et al./10/. As is shown in Fig. 3 the measured total resonant absorption area is increased and the temperature dependence of $\mathrm{A}$ is drastically changed upon embedding the catalyst precursor. Between $77 \mathrm{~K}$ and $300 \mathrm{~K}$, the temperature dependence of $\mathrm{A}$ in the embedded sample corresponds to the behaviour of fixed iron(III) oxide particles of this size $(\approx 30-40 \AA)$. However, between $77 \mathrm{~K}$ and $4.2 \mathrm{~K}$ A of the embedded sample increases much more with decreasing temperature than $A$ of the non-embedded sample. This indicates that due to the paraffin matrix also a fraction of the original iron(III) oxide particles, missing in 
the spectrum due to the large thermal motions of the particles, becomes stronger bound to the support. However still not completely fixed.

By using ethanol as a solvent, the pore volume of the carbonsupport turns out to be higher $\left(1.2 \times 10^{-3} \mathrm{~m} / \mathrm{kg}\right)$ than for water $\left(1.0 \times 10^{-3} \mathrm{~m}^{3} / \mathrm{kg}\right)$. In order to achieve a higher dispersion of the iron(III) oxide particles we have measured a $\mathrm{Fe} / \mathrm{C}$ catalyst precursor obtained by impregnation with a solution of $\mathrm{Fe}\left(\mathrm{NO}_{3}\right)_{3} \cdot 9 \mathrm{H}_{2} \mathrm{O}$ in ethanol (see Fig.le). The spectrum is more complicated than when an aqueous solution is used. A larger fraction of the spectral area is due to paramagnetic relaxation of moncatomically dispersed $\mathrm{Fe}$, influenced by anionic species present on the support. So it turns out that indeed a higher dispersion can be achieved by using ethanol as a solvent. Investigations of the effect on the catalytic activity are in progress.

\section{CONCLUSIONS}

There exists an optimum evaporation rate of the impregnated solvent in relation to the highest dispersion of the catalyst precursor. By using that drying prodedure the particles are then most strongly bound to the support and so less sintering sensitive.

It seems to be worthwhile to investigate the catalytic activity of $\mathrm{Fe} / \mathrm{C}$ catalysts obtained by impregnation with a solution of $\mathrm{Fe}\left(\mathrm{NO}_{3}\right)_{3} \cdot 9 \mathrm{H}_{2} \mathrm{O}$ in ethanol.

For the bimetallic FeMo/C catalyst precursor an influence of the drying procedure on the dispersion of the catalyst has not been observed. A possible explanation for this phenomenon is that in FeMo/C the $\mathrm{Fe}$ is supported by the molybdenum rather than by the carbon. This result would be in agreement with measurements on COMO/ $\mathrm{Al}_{2} \mathrm{O}_{3}$ catalysts $/ 2 /$.

\section{REFERENCES}

/ 1/ H. Topsфe, J.A. Dumesic and S. Mфrup in "Application of Mössbauer Spectroscopy" (R.L. Cohen, Ed.) Vo1.II, p.55, Academic Press, New York 1980.

$/ 2 /$ H. Topsфe, R. Candia, N.-Y. Topsфe and B.S. Clausen, Bull. Soc. Chim. Belg. 93(1984)783.

/ 3/ J.C. Duchet, E.M. van Oers, V.H.J. de Beer and R. Prins, J. Catal. 80(1983)386.

/ 4/ C.K. Groot, Thesis, Eindhoven University of Technology, Eindhoven 1984.

/ 5/ A.M. van der Kraan, Phys. Stat. Sol.(a) 18(1973) 215.

/ 6/ J.W. Niemantsverdriet, A.M. van der Kraan and W.N. Delgass, J. Catal. 89(1984) 138.

$/ 7 /$ M.P.A. Viegers and J.M. Trooster, Phys. Rev. BI5(1977) 72.

/ 8/ H.-J. Jung, M.A. Vannice, L.N. Mulay, R.M. Stanfield and W.N. Delgass, J. Catal. 76(1982) 208.

/ 9 / J.W. Niemantsverdriet, A.M. van der Kraan, W.N. Delgass and M.A. Vannice, J. Phys. Chem. 89(1985)67.

$/ 10 /$ M. Hayashi, I. Tamura, Y. Fukano, S. Kanemaki and Y. Fujio, J. Phys. C. Solid St. Phys. 13(1980)681. 